\title{
Direct Determination of Lanthanides in Environmental Samples using Ultrasonic Nebulization and ICP OES
}

\author{
Fabrina R. S. Bentlin and Dirce Pozebon* \\ Instituto de Química, Universidade Federal do Rio Grande do Sul, Av. Bento Gonçalves, 9500, \\ 91501-970 Porto Alegre-RS, Brazil
}

\begin{abstract}
Baixas concentrações dos catorze elementos de ocorrência natural da série lantanídeos foram diretamente determinadas por espectrometria de emissão óptica com plasma indutivamente acoplado (ICP OES). Avaliaram-se interferências espectrais e linhas espectrais mais adequadas foram selecionadas. Os desempenhos da nebulização pneumática e ultra-sônica foram comparados com respeito aos limites de detecção, para ambas as posições de observação do plasma, radial e axial. A influência da potência de radiofrequência sobre a precisão e exatidão foi também investigada para os dois tipos de nebulizadores. O método foi aplicado à determinação dos lantanídeos em amostras ambientais (sedimentos, cinza de carvão e água fluvial). Este trabalho demonstrou que é possível a determinação direta de baixas concentrações (i.e. $\mathrm{ng} \mathrm{g}^{-1} \mathrm{e} \mathrm{ng} \mathrm{L}^{-1}$ ) dos lantanídeos de ocorrência natural por ICP OES.
\end{abstract}

Low concentrations of the fourteen naturally occurring lanthanides were directly determined by inductively coupled plasma optical emission spectrometry (ICP OES). Spectral interferences were evaluated and the most appropriate spectral lines selected. Pneumatic and ultrasonic nebulization performances were compared with respect to limits of detection for both radial and axial viewed plasma. The influence of plasma applied power on precision and accuracy was studied for both nebulizers. The developed method was applied to lanthanides determination in environmental samples (sediments, coal fly ash and river water). This work demonstrates that the use of ultrasonic nebulization combined with axially viewed plasma allowed direct determination of low concentrations (at ng $\mathrm{g}^{-1}$ and $\mathrm{ng} \mathrm{L}^{-1}$ levels) of all naturally occurring lanthanides by ICP OES.

Keywords: lanthanides, ICP OES, ultrasonic nebulization, pneumatic nebulization, environmental samples

\section{Introduction}

The elements of the lanthanides series, ranging from lanthanum to lutetium comprises fithteen homologous trivalent metals, of which fourteen commonly occur in nature. Promethium does not occur naturally. Lanthanides mobilization from their natural sources has increased in the last decades. Because of their diversified physical and chemical properties, the lanthanides elements have been widely used in a number of fields (e.g., in microelectronics and optics, in material science or in nuclear reactors, in biomolecular research or in medical diagnostics). ${ }^{1-3}$ The lanthanides are also often used in fertilizers ${ }^{4}$ or as feeding markers in nutritional and agronomic studies. ${ }^{4-6}$ These elements have also been used as fingerprint markers for

*e-mail: dircepoz@iq.ufrgs.br cement and concrete ${ }^{7}$ and in geological ${ }^{8}$ or palenteology studies. $^{9}$

Uses and applications of lanthanides are still increasing and so are the associated emissions to the environment. In recent years, lanthanides-rich fertilizers have being widely used in China to enhance yield and improve crop quality. It is reported that application of these fertilizers not only increases the yield but also brings many visual benefits to plants including darker green foliage, enhanced development rate, greater production of roots, as well as better fruit color. ${ }^{10}$ It is expected that agricultural usage of lanthanides will grow.

It has already been observed that $\mathrm{Ce}, \mathrm{Pr}$ and $\mathrm{Lu}$ can accumulate in liver affecting cell physiology. These effects appeared to result from the similarity of lanthanides cationic radii to the size of $\mathrm{Ca}^{2+}$ ions. Trivalent lanthanide ions, especially $\mathrm{La}^{3+}$ and $\mathrm{Gd}^{3+}$, block different calcium channels 
in human and animal cells and also affect numerous enzymes. ${ }^{11,12}$ Furthermore, the biological effects of the lanthanides in living organisms, based on their similarity to calcium, have stimulated researches into their therapeutic application..$^{13}$ Therefore, lanthanides determination in environment samples is of increasing importance due to the accelerated input by anthropogenic activities and possible contamination.

The lanthanides elements are chemically and physically similar, have complex absorption and emission spectra, and are generally present in low concentration in environmental samples. Therefore, multi-element determination of all naturally occurring lanthanides is usually troublesome. Inductively coupled plasma optical emission spectrometry (ICP OES) and inductively coupled plasma mass spectrometry (ICP-MS) are very feasible techniques for quantitative determination of the lanthanides. The most important advantages of these techniques are high sample throughput, simplicity and good sensitivity, in comparison to other techniques ${ }^{14,15}$ used for lanthanides determination.

Matrix separation/analyte pre-concentration has been used until now in the determination of lanthanides by ICP OES in order to overcome spectral interferences and/or improve the limits of detection (LODs) ${ }^{16-21}$ Navarro et $a l .^{20}$ determined lanthanides in geological materials, but matrix separation was performed in cationic exchange column prior analyte determination by ICP OES, and ultrasonic nebulization was used for introducing the sample solution in the plasma. In another work, ${ }^{21}$ nine lanthanides elements were determined in silicate rocks using ultrasonic nebulization and ICP OES; online ion-exchange was used for iron separation prior to analyte determination.

The ICP-MS technique due to its higher sensitivity and lower spectral interferences seems more appropriate than ICP OES for determination of lanthanides at trace levels. However, the determination may be difficult due to isobaric interferences, particularly oxides and hydroxides. ${ }^{22}$ Consequently, special nebulizers may be necessary for sample introduction into the plasma. Nowadays, due to the higher sensitivity achieved with axially viewed plasma and better spectral resolution given by high-resolution monochromators, it is expected that low concentrations of all naturally occurring lanthanides may be directly quantified by ICP OES. Furthermore, depending on the nebulizer used to introduce the sample solution in the plasma, sensitivity improves. By using ultrasonic nebulizer or pneumatic nebulizer coupled to a dessolvator system the amount of solvent entering the plasma can be drastically reduced and sensitivity improved. ${ }^{23-25}$ However, the occurrence of spectral interferences needs to be rigorously controlled in order to achieve precise and accurate results.
Moreover, the reagents used in the decomposition of the sample must be evaluated, since the lanthanides precipitated in presence of $\mathrm{HF}^{26}{ }^{26}$ which is commonly used to decompose environmental samples.

The aim of the present study was to develop a method for the determination of all naturally occurring lanthanides in environmental samples by using ICP OES, without matrix separation. The objectives set include (i) finding out appropriate spectral lines, (ii) develop a procedure for sample preparation and (iii) select a feasible nebulizer for introducing the sample solution into the plasma.

\section{Material and Methods}

\section{Instrumentation}

All determinations were performed using an Optima ${ }^{\mathrm{TM}}$ 2000 DV ICP OES sequential spectrometer (Perkin-Elmer, Shelton, CT, USA). An ultrasonic nebulizer (US-5000 AT+ from CETAC, Omaha, NE, USA), pneumatic nebulizer (MicroMist MCN-600 from Glass Expansion, Pocasset, MA, USA) attached to a Cinnabar cyclonic spray chamber (from Glass Expansion) and a 2-mm injector tube made of alumina were used for introducing the sample solution into the plasma. The heating and cooling temperatures of the ultrasonic nebulizer were 140 and $-4{ }^{\circ} \mathrm{C}$, respectively. In order to avoid any carry-over effect, the ultrasonic nebulizer was washed out with $1 \%(\mathrm{v} / \mathrm{v}) \mathrm{HNO}_{3}$ for $60 \mathrm{~s}$ between each sample run. The instrumental parameters are shown in Table 1. The following spectral lines (wavelength in $\mathrm{nm}$ ) were monitored: La-392.852, 408.672, 379.478, 333.749, 379.083, 403.169, 407.733, 384.902; Ce-418.660, 413.380, 394.724, 456.236; Pr-390.844, 414.311, 422.293; Nd406.109, 401.225, 430.358, 424.738, 384.824; Sm-359.260, 442.434, 360.949, 388.529, 428.079; Eu-381.967, 412.97, 393.048; Gd-342.247, 336.223, 335.047, 376.839; Tb350.917, 384.873, 367.635; Dy-353.170, 364.540, 394.468, 407.796; Но-339.898, 347.426, 345.600; Er-337.271, 369.265, 349.910; Tm-384.802, 346.220, 313.126, 336.261, 324.154; Yb-328.937, 369.419; Lu-261.542 and 291.139. All emission lines monitored are ionic (II). For Eu determination in the Tibet sediment by ICP-MS, an ELAN DRC II instrument (from PerkinElmer/SCIEX) was employed. Ultrasonic nebulization was used for introducing the sample solution into the plasma.

\section{Standards and reagents}

All chemicals used were of analytical grade (Merck, Darmstadt, Germany). All solutions and samples were prepared with high purity deionised water $(18.2 \mathrm{M} \Omega \mathrm{cm})$ 
Table 1. ICP OES: Operational conditions and instrumental parameters

\begin{tabular}{|c|c|}
\hline RF power/kW & $1.1-1.5$ \\
\hline Plasma gas flow rate/(L $\left.\mathrm{min}^{-1}\right)$ & 15 \\
\hline Auxiliary gas flow rate/( $\left.\mathrm{L} \mathrm{min}^{-1}\right)$ & 0.2 \\
\hline $\begin{array}{l}\text { Nebulizer carrier gas flow rate/ } \\
\left.(\mathrm{L} \mathrm{min})^{-1}\right)\end{array}$ & $\begin{array}{l}0.75 \text { (pneumatic nebulizer) and } \\
0.70 \text { (ultrasonic nebulizer) }\end{array}$ \\
\hline $\begin{array}{l}\text { Sample flow rate/ } \\
\left(\mathrm{L} \mathrm{min}^{-1}\right)\end{array}$ & $\begin{array}{l}0.75 \text { (pneumatic nebulizer) and } \\
2.5 \text { (ultrasonic nebulizer) }\end{array}$ \\
\hline Plasma view mode & axial and radial \\
\hline Resolution & high \\
\hline Background correction & 2 points per peak \\
\hline Integration time/s & $2.5-5.0$ \\
\hline Signal processing & peak area (3-7 points per peak) \\
\hline
\end{tabular}

obtained from a Milli-Q system (Millipore, Bedford, MA, USA). Calibration solutions were prepared from serial dilutions of mono-element standard solutions from Merck. The calibration was performed with a multi-element mixed solution in $5 \%(\mathrm{v} / \mathrm{v}) \mathrm{HNO}_{3}$. The concentrations of the calibration solutions ranged from 1.0 to $25 \mu \mathrm{g} \mathrm{L}^{-1}$, depending on the lanthanide element, nebulizer type and plasma view. Each calibration curve was obtained by using at least five calibration solutions with different concentrations.

\section{Samples and sample preparation}

Coal fly ash (SRM 1633b, from the National Institute of Standards and Technology - NIST, Gaithersburg, MD, USA) was used for method development. River sediment (BCR 320, from the Community Bureau of Reference, Geel, Belgium), Tibet sediment (NCS DC70319) and river water were further analyzed. The water sample was taken from Guaíba River (Porto Alegre, RS, Brazil). This river receives water from other rivers that crosses large agricultural areas where a number of different plantations are grown. The water sample was collected by using a decontaminated polyethylene flask, which was subsequently carried to the laboratory where the sample was filtered (a quantitative Whatman filter paper for fast filtration was used) and acidified up to $5 \%$ (v/v) $\mathrm{HNO}_{3}$. Two different procedures were used for the coal fly ash and sediments samples decomposition: (A) three $150 \mathrm{mg}$ aliquots of sample were transferred to PTFE pumps to which $7 \mathrm{~mL}$ of $\mathrm{HNO}_{3}, 2 \mathrm{~mL}$ of $\mathrm{HF}$ and $2 \mathrm{~mL}$ of $\mathrm{H}_{2} \mathrm{O}_{2}$, all them concentrated, were added and the mixture let standing for $60 \mathrm{~min}$. After closing with screw caps, the pumps containing the mixture were heated in a metallic block (TE 0070 Tecnal, Piracicaba, SP, Brazil) for a period of $6 \mathrm{~h}$ at $200{ }^{\circ} \mathrm{C}$. After cooling to room temperature, $4 \mathrm{~mL}$ of $20 \%$ $(\mathrm{m} / \mathrm{v}) \mathrm{H}_{3} \mathrm{BO}_{3}$ were added and the mixture heated again for $90 \mathrm{~min}$ at $160{ }^{\circ} \mathrm{C}$. Afterwards, the heating was turned off and the solution let standing to achieve room temperature. Then, the flask was opened and the digest was transferred to a graduated flask made of polypropylene. The volume was made up to $50 \mathrm{~mL}$. For recovery tests, aliquots of the analyte solution were added to the sample (in triplicate) before its decomposition, with replicates of the sample without addition of the analyte; (B) $200 \mathrm{mg}$ aliquots of sample were transferred to Pt crucibles followed by the addition of $2 \mathrm{~mL}$ of concentrated $\mathrm{HNO}_{3}$. The crucibles were placed on a hot plate and heated in order to evaporate the acid. After, a volume of $2 \mathrm{~mL}$ of concentrated HF was added and also evaporated. Subsequently, $1 \mathrm{~g}$ of $\mathrm{Na}_{2} \mathrm{~B}_{4} \mathrm{O}_{7} \cdot 7 \mathrm{H}_{2} \mathrm{O}$ (from Merck) was added and the crucibles were placed in a muffle furnace. The temperature of the furnace was increased up to $1,100{ }^{\circ} \mathrm{C}$ and kept for $1 \mathrm{~h}$. After cooling to room temperature, a transparent melt was observed, which was dissolved by immersion of the crucible in $10 \%(\mathrm{v} / \mathrm{v})$ $\mathrm{HCl}$ solution under heating (about $90^{\circ} \mathrm{C}$ ). Once the melt was dissolved, the crucible was removed from the sample solution. Then, this solution was evaporated to about $10 \mathrm{~mL}$ and transferred to a polyethylene flask containing $1 \mathrm{~mL}$ of concentrated $\mathrm{HNO}_{3}$ and the volume made up to $50 \mathrm{~mL}$ with water. This solution was ten-fold diluted with water before introduction into the plasma using an ultrasonic nebulizer.

\section{Results and Discussion}

\section{Method development}

Investigations were made with respect to possible spectral interferences and sensitivity, using mono or multielement solutions with all lanthanides in the same solution and at the same concentration $\left(2.0 \mu \mathrm{g} \mathrm{L}^{-1}\right.$ and $20 \mu \mathrm{g} \mathrm{L}^{-1}$ for ultrasonic and pneumatic nebulizer, respectively). The signals of the analytes were measured by using both radially and axially viewed plasma, and at least two spectral lines per element were monitored. Limits of detection, LODs, for all investigated spectral lines are show in Table S1 (see Supplementary Information). The spectral lines shown in Table 2 were selected because no spectral interferences between the lanthanides were observed and/or the better LODs obtained.

It was further observed that $\operatorname{Pr} 414.311 \mathrm{~nm}, \mathrm{Sm}$ $360.949 \mathrm{~nm}$ and Gd $335.047 \mathrm{~nm}$ should be used (instead of Pr $390.844 \mathrm{~nm}, \mathrm{Sm} 359.260 \mathrm{~nm}$ and Gd $342.247 \mathrm{~nm}$ ) for Pr, Sm and Gd determination in coal fly ash, in order to obtain accurate results. The lanthanides may interfere with each other ${ }^{27,28}$ and Dy (spectral lines at 390.840, 359.316 
Table 2. Selected spectral lines of the lanthanides and respective ICP OES limits of detection (in $\left.\mu \mathrm{g} \mathrm{L}^{-1}\right)$ as a function of the nebulizer and plasma view

\begin{tabular}{|c|c|c|c|c|c|c|}
\hline \multirow{3}{*}{ Analyte } & \multicolumn{4}{|c|}{ Nebulizer and Plasma View } & \multirow{3}{*}{$\begin{array}{c}\text { Reference } 21 \\
\text { (ICP OES) }\end{array}$} & \multirow{3}{*}{$\begin{array}{c}\text { Reference } 23 \\
\text { (ICP-MS) }\end{array}$} \\
\hline & \multicolumn{2}{|c|}{ Pneumatic } & \multicolumn{2}{|c|}{ Ultrasonic } & & \\
\hline & Axial & Radial & Axial & Radial & & \\
\hline La (II) 398.852 & 0.164 & 0.818 & 0.010 & 0.073 & 0.30 & 0.004 \\
\hline Ce (II) 413.380 & 1.436 & 4.799 & 0.069 & 0.272 & $0.93^{\mathrm{b}}$ & 0.004 \\
\hline $\operatorname{Pr}($ II) 414.311 & 1.114 & 2.767 & 0.036 & 0.237 & - & 0.003 \\
\hline $\operatorname{Pr}\left(\right.$ II) $390.844^{\mathrm{a}}$ & 0.834 & 3.401 & 0.041 & 0.205 & - & - \\
\hline Nd (II) 406.109 & 1.252 & 2.696 & 0.060 & 0.194 & $0.51^{\mathrm{c}}$ & 0.018 \\
\hline Sm (II) 360.949 & 0.804 & 2.023 & 0.062 & 0.417 & - & 0.016 \\
\hline Sm (II) $359.260^{\mathrm{a}}$ & 2.077 & 3.398 & 0.039 & 0.221 & 0.25 & - \\
\hline Eu (II) 381.967 & 0.034 & 0.140 & 0.003 & 0.019 & 0.045 & 0.011 \\
\hline Gd (II) 335.047 & 0.504 & 2.684 & 0.036 & 0.309 & - & 0.013 \\
\hline Gd (II) $342.247^{\mathrm{a}}$ & 0.196 & 0.659 & 0.012 & 0.106 & 0.72 & - \\
\hline $\mathrm{Tb}$ (II) 350.917 & 0.349 & 1.942 & 0.023 & 0.211 & - & 0.004 \\
\hline $\mathrm{Tb}$ (II) $367.635^{\mathrm{a}}$ & 1.354 & 4.610 & 0.039 & 0.239 & - & - \\
\hline Dy (II) 353.170 & 0.165 & 0.579 & 0.007 & 0.045 & - & 0.011 \\
\hline Но (II) 345.600 & 0.167 & 0.512 & 0.008 & 0.065 & - & 0.004 \\
\hline $\operatorname{Er}$ (II) 349.910 & 0.160 & 0.922 & 0.013 & 0.137 & $0.12^{\mathrm{d}}$ & 0.012 \\
\hline $\operatorname{Tm}$ (II) 384.802 & 0.433 & 1.050 & 0.009 & 0.080 & - & 0.003 \\
\hline Yb (II) 328.937 & 0.018 & 0.061 & 0.003 & 0.090 & 0.01 & 0.010 \\
\hline Lu (II) 261.542 & 0.017 & 0.124 & 0.003 & 0.014 & 0.006 & 0.003 \\
\hline
\end{tabular}

${ }^{a}$ for the analyte determination in Tibet sediment; emission lines: ${ }^{\mathrm{b}} 418.660 \mathrm{~nm},{ }^{\mathrm{c}} 430.358 \mathrm{~nm}$ and ${ }^{\mathrm{d}} 390.631 \mathrm{~nm}$.

and $342.239 \mathrm{~nm})^{27}$ may interfere on $\mathrm{Pr}, \mathrm{Sm}$ and $\mathrm{Gd}$, which depends on the concentrations of these elements in the sample. A more sensitive spectral line of $\mathrm{Tb}$ (at $350.917 \mathrm{~nm}$ ) could not be used due to Pr interference (Pr $350.918 \mathrm{~nm}),{ }^{28}$ and this was observed for the Tibet sediment sample.

The LOD for each spectral line was obtained from $\mathrm{b}+3 s$ where $\mathrm{b}$ is the mean concentration of 10 consecutive measurements of the blank $\left(5 \% \mathrm{v} / \mathrm{v} \mathrm{HNO}_{3}\right)$ and $s$ is the standard deviation. As expected, the lowest LODs were obtained by using ultrasonic nebulization and axially viewed plasma (Table 3). The best LODs obtained with ultrasonic nebulization are mainly due to the greater aerosol output of the ultrasonic nebulizer (the sample uptake rate and aerosol transportation to the plasma are higher than those of the MicroMist nebulizer). The LODs found using ultrasonic nebulization and axially viewed plasma are lower than those reported for $\mathrm{La}, \mathrm{Ce}, \mathrm{Nd}, \mathrm{Sm}, \mathrm{Eu}, \mathrm{Er}$ and $\mathrm{Yb}$, measured using ultrasonic nebulization, ICP OES and matrix removal. ${ }^{21}$ For comparison purposes, the LODs obtained using ICP-MS and pneumatic nebulization ${ }^{23}$ are also shown in Table 2. It can be seen in this table that LODs found using ultrasonic nebulization and axially viewed plasma are in general only one order of magnitude higher, or less, than those found by ICP-MS.
The nebulizer gas flow rate in pneumatic nebulization and plasma power can have a major effect on the formation of oxides of lanthanides, as well as in emission intensity and plasma robustness. Robust conditions of the plasma have been associated to high applied power by radiofrequency generator, low carrier gas flow rate and large diameter of the injector. ${ }^{29,30}$ For robustness quantification, the ratio of the emission intensities of two magnesium lines (atomic and ionic transition) has been used. The plasma has been considered robust if the ratio $\mathrm{Mg}$ (II) $280.271 \mathrm{~nm} / \mathrm{Mg}$ (I) $285.213 \mathrm{~nm}$ is 10 or greater. In the present work, the plasma robustness was evaluated for both the pneumatic and ultrasonic nebulizers (Figure 1). For the pneumatic nebulizer, the plasma can be considered robust when the RF power ranged from 1.3 to $1.5 \mathrm{~kW}$, and the nebulizer gas flow rate from 0.6 to about $0.8 \mathrm{~mL} \mathrm{~min}^{-1}$. The results found (Figure 1) are in agreement with previous reported data. ${ }^{29,30}$ However, the plasma cannot be considered robust when ultrasonic nebulization was used. According to reported results, ${ }^{31}$ the $\mathrm{Mg}(\mathrm{II}) / \mathrm{Mg}(\mathrm{I})$ ratio was lower than 5 when solutions of digested plants were introduced into the plasma by means of ultrasonic nebulization. In another work, ${ }^{32}$ the $\mathrm{Mg}$ (II)/Mg(I) ratio found was about 7 in the absence of matrix. The degradation in the $\mathrm{Mg}(\mathrm{II}) / \mathrm{Mg}(\mathrm{I})$ ratio in matrix solutions can be caused by higher matrix loading in the plasma, lowering the plasma robustness. ${ }^{31}$ 
It had been observed ${ }^{23}$ that the signals of the lanthanides elements measured by ICP-MS remained almost the same while the oxides formation rate was reduced when a MicroMist nebulizer and carrier gas flow rate between 0.75 and $0.95 \mathrm{~L} \mathrm{~min}^{-1}$ were used. In this work, the nebulizer gas flow rate was varied in the range of 0.60 to $0.80 \mathrm{~L} \mathrm{~min}^{-1}$ and the maximum signal was observed at $0.75 \mathrm{~L} \mathrm{~min}^{-1}$. This condition was then established for further measurements by using this nebulizer. According to Figure 1, the $\mathrm{Mg}(\mathrm{II}) /$ $\mathrm{Mg}(\mathrm{I})$ ratio is close to 10 when the nebulizer gas flow rate is 0.75 , which means the plasma is still robust.
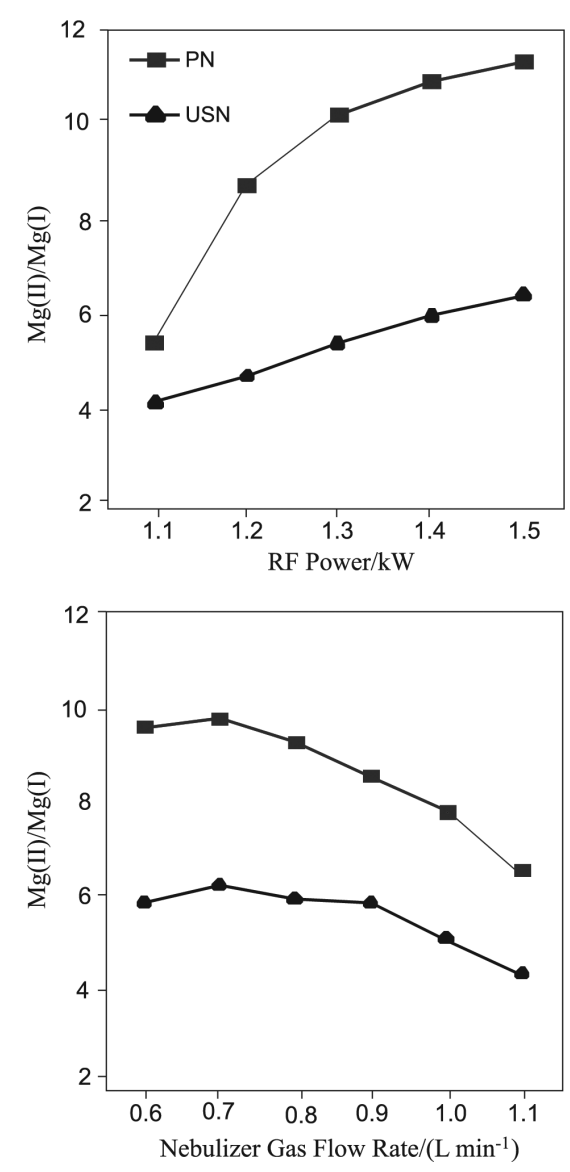

Figure 1. Effect of RF applied power and nebulizer gas flow rate on $\mathrm{Mg}(\mathrm{II}) / \mathrm{Mg}(\mathrm{I})$ intensities ratio for pneumatic (PN) and ultrasonic (US) nebulizers. For the RF study the nebulizer gas flow rate was kept in $0.75 \mathrm{~L} \mathrm{~min}^{-1}$, whereas the RF was kept in $1.5 \mathrm{~kW}$ for the nebulizer gas flow rate study. The Tibet sediment sample was used, which was prepared according to acid decomposition procedure (A).

The performance of the ultrasonic and pneumatic nebulizers as a function of plasma applied power is shown in Figure 2 for coal fly ash.

Figure 2 shows that precision and accuracy were better for most elements when ultrasonic nebulization was used for introducing the sample solution into the plasma. In this case, the RF power can be set at $1.3 \mathrm{~kW}$ for La, $\mathrm{Tb}, \mathrm{Nd}, \mathrm{Dy}, \mathrm{Ho}, \mathrm{Yb}$ Pr and Er; $1.4 \mathrm{~kW}$ for Ce, Gd and
$\mathrm{Sm}$; and $1.2 \mathrm{~kW}$ for $\mathrm{Tm}$ and $\mathrm{Lu}$. These conditions were established for further experiments. Taking into account pneumatic nebulization, RF applied power can be $1.4 \mathrm{~kW}$ for $\mathrm{Ce}$ and $\mathrm{Gd}$, and $1.3 \mathrm{~kW}$ for $\mathrm{Eu}, \mathrm{Tb}, \mathrm{Sm}, \mathrm{Dy}, \mathrm{Ho}, \mathrm{Yb}$ and Er. It is observed the concentrations of $\mathrm{Tm}, \mathrm{Nd}, \mathrm{Lu}$, $\mathrm{Pr}, \mathrm{Eu}, \mathrm{La}$ and $\mathrm{Ce}$ found are lower than the expected values at any RF applied power tested using the pneumatic nebulizer. The best performance observed for ultrasonic nebulizer can be explained by the quality of the produced aerosol. Significant amounts of the aerosol droplets are distributed over at least one order of magnitude, whereas the diameter of $90 \%$ of droplets is greater than $4 \mu \mathrm{m}$ and lower than $30 \mu \mathrm{m} .{ }^{33}$ Although the ultrasonic nebulizer generates aerosols with significantly broader particle size distributions than concentric pneumatic nebulizer, the ultrasonic nebulizer produces an aerosol of much greater particles density than the pneumatic nebulizer.. ${ }^{33}$ The higher aerosol density ultimately results in the production of many more appropriately sized droplets than found with pneumatic nebulizer, making the conversion to atomic and ionic species easier. ${ }^{33}$ Furthermore, aerosol desolvation minimizes the oxide formation rate $^{23}$ and improves the plasma characteristics. ${ }^{32}$ Therefore, despite the larger sample consumption, ultrasonic nebulization is advantageous for lanthanides determination by ICP OES in comparison to the conventional pneumatic nebulization. As a result of the better results obtained, the ultrasonic nebulizer was used for lanthanides determination in environmental samples.

Sample analysis

The applicability of the method was evaluated for river water, coal fly ash and sediment samples. The concentrations found are shown in Table 3 and they are in agreement with those reported in the certificate or obtained for spiked samples, except for Eu in river sediment. Since the informed concentration is different of that found, Eu was also determined in this sample by ICP-MS with an ultrasonic nebulizer. According to Table 3, the Eu concentration determined by ICP-MS agrees with that found by ICP OES.

Most lanthanides were not detected in river water, which shows that contamination by those elements fortunately is still low. It was observed that both procedures investigated for sample decomposition can be used. However, the sample solution obtained by fusion needs to be more diluted to reduce matrix interferences caused by the fusion agent in the plasma and also prevent clogging of the MicroMist nebulizer. Therefore, the procedure (A) (acid decomposition) is recommended because it is faster 

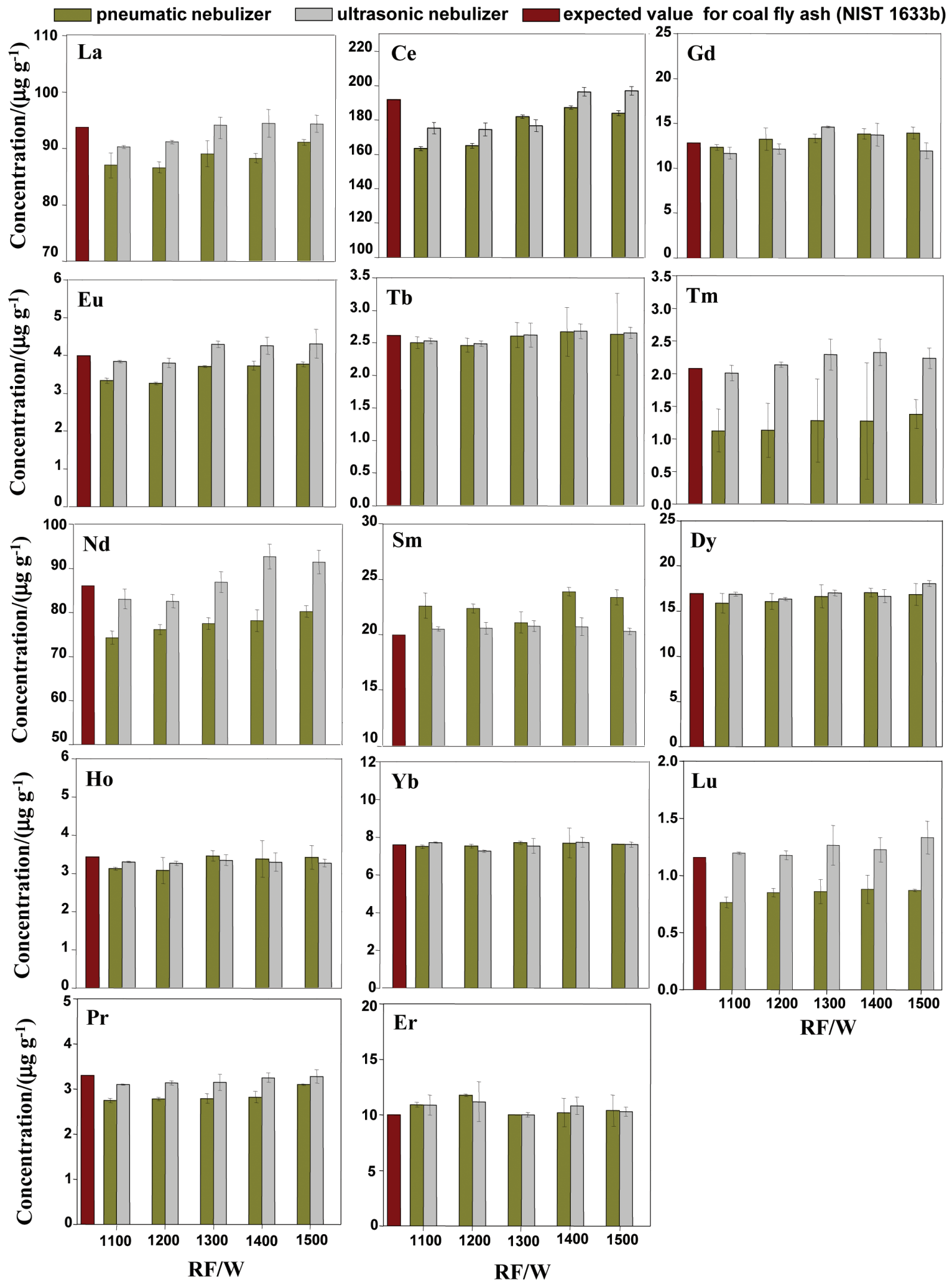

Figure 2. Influence of plasma applied power on precision and accuracy; sample flow rate: 0.75 and $2.5 \mathrm{~mL} \mathrm{~min}^{-1}$ for pneumatic and ultrasonic nebulizers, respectively; plasma view: axial. Error bars are the standard deviation of three replicates of the sample. A new calibration curve was obtained for each RF applied power setting. The expected values are informed on the certificate, except for Pr that was spiked. Procedure (A) was used for sample decomposition. 
Table 3. Lanthanides concentration found in certified reference materials by using ultrasonic nebulizer and axially viewed plasma; uncertainties are the standard deviations for three samples replicates $(n=3)$. The spectral lines shown in Table 2 were monitored. The coal fly ash and sediment were acid decomposed according to procedure (A)

\begin{tabular}{|c|c|c|c|c|c|c|c|}
\hline \multirow{2}{*}{ Element } & \multicolumn{2}{|c|}{ Coal fly ash ( $\left.\mu \mathrm{g} \mathrm{g}^{-1}\right)$} & \multicolumn{2}{|c|}{ River sediment $\left(\mu \mathrm{g} \mathrm{g}^{-1}\right)$} & \multicolumn{2}{|c|}{ Tibet sediment $\left(\mu \mathrm{g} \mathrm{g}^{-1}\right)$} & \multirow{2}{*}{$\begin{array}{c}\text { River water }\left(\mu \mathrm{g} \mathrm{L}^{-1}\right) \\
\text { Found }\end{array}$} \\
\hline & Informed $^{\mathrm{a}}$ & Found & Informed $^{\mathrm{a}}$ & Found & Certified & Found & \\
\hline $\mathrm{La}$ & 94 & $94.6 \pm 1.6$ & 45.7 & $44.7 \pm 1.6$ & $42.6 \pm 2.4$ & $42.1 \pm 0.9$ & $<0.010$ \\
\hline $\mathrm{Ce}$ & 190 & $195 \pm 3$ & 94.4 & $98.9 \pm 1.7$ & $78.1 \pm 4.6$ & $78.5 \pm 2.3$ & $0.72 \pm 0.02$ \\
\hline $\operatorname{Pr}$ & $3.3^{\mathrm{b}}$ & $3.2 \pm 0.3$ & $0.50^{\mathrm{b}}$ & $0.48 \pm 0.04$ & $8.57 \pm 0.43$ & $8.96 \pm 0.28$ & $<0.036$ \\
\hline $\mathrm{Nd}$ & 85 & $86.3 \pm 1.8$ & - & $43.9 \pm 0.5$ & $30.6 \pm 0.8$ & $28.7 \pm 1.4$ & $0.36 \pm 0.01$ \\
\hline $\mathrm{Sm}$ & 20 & $20.3 \pm 0.3$ & - & $11.3 \pm 0.7$ & $5.42 \pm 0.30$ & $5.36 \pm 0.71$ & $<0.062$ \\
\hline $\mathrm{Eu}$ & 4.1 & $4.42 \pm 0.41$ & $1.6 ; 2.02 \pm 0.17^{\mathrm{c}}$ & $2.12 \pm 0.11$ & $0.97 \pm 0.05$ & $1.03 \pm 0.02$ & $<0.003$ \\
\hline Gd & 13 & $12.1 \pm 0.9$ & - & $65.2 \pm 2.0$ & $4.57 \pm 0.23$ & $4.65 \pm 0.13$ & $<0.036$ \\
\hline $\mathrm{Tb}$ & 2.6 & $2.64 \pm 0.09$ & $1.0^{\mathrm{b}}$ & $1.1 \pm 0.1$ & $0.70 \pm 0.04$ & $0.86 \pm 0.13$ & $<0.023$ \\
\hline Dy & 17 & $18.1 \pm 0.3$ & - & $3.40 \pm 0.10$ & $3.91 \pm 0.21$ & $3.60 \pm 0.18$ & $<0.007$ \\
\hline Но & 3.5 & $3.34 \pm 0.10$ & $2.50^{\mathrm{b}}$ & $2.53 \pm 0.03$ & $0.79 \pm 0.06$ & $0.71 \pm 0.04$ & $<0.008$ \\
\hline $\mathrm{Er}$ & $10.4^{\mathrm{b}}$ & $10.9 \pm 0.9$ & - & $4.32 \pm 0.08$ & $2.39 \pm 0.12$ & $2.45 \pm 0.09$ & $<0.013$ \\
\hline $\mathrm{Tm}$ & 2.1 & $2.26 \pm 0.16$ & - & $0.63 \pm 0.02$ & $0.38 \pm 0.02$ & $0.43 \pm 0.03$ & $<0.009$ \\
\hline $\mathrm{Yb}$ & 7.6 & $7.62 \pm 0.12$ & - & $2.39 \pm 0.02$ & $2.55 \pm 0.08$ & $2.24 \pm 0.15$ & $<0.003$ \\
\hline $\mathrm{Lu}$ & 1.2 & $1.38 \pm 0.15$ & - & $0.37 \pm 0.02$ & $0.39 \pm 0.02$ & $0.41 \pm 0.02$ & $<0.003$ \\
\hline
\end{tabular}

${ }^{a}$ Informed on certificates; ${ }^{\mathrm{b}}$ Spiked; ${ }^{\mathrm{c}}$ Determined by ICP-MS. Those lines marked with ${ }^{\mathrm{a}}$ in Table 2 were used only for the Tibet sediment.

and easier to carry out than the procedure (B) (alkaline fusion). It is important to mention that the $\mathrm{H}_{3} \mathrm{BO}_{3}$ addition not only dissolves the precipitated-lanthanides fluorides, ${ }^{26}$ but also neutralize the HF, avoiding damage of the sample introduction system and quartz torch.

\section{Conclusions}

This study demonstrated the applicability of the ICP OES technique for direct determination of low concentrations of lanthanides in environmental samples. By monitoring the most sensitive spectral lines when possible, using ultrasonic nebulizer and plasma with axial view of observation, concentration at $\mathrm{ng} \mathrm{g}^{-1}$ or $\mathrm{ng} \mathrm{L}^{-1}$ levels can be accurately determined. Both accuracy and precision were improved when using ultrasonic nebulizer in comparison to conventional pneumatic nebulizer. Siliceous samples can be decomposed efficiently with $\mathrm{HNO}_{3}, \mathrm{HF}$ and $\mathrm{H}_{2} \mathrm{O}_{2}$ and conventional heating in PTFE closed vessels for the determination of lanthanides by ICP OES, but the addition of $\mathrm{H}_{3} \mathrm{BO}_{3}$ is necessary to obtain accurate results.

\section{Supplementary Information}

Supplementary data (limits of detection for all investigated spectral lines are shown inTable S1) and are available free of charge at http://jbcs.sbq.org.br, as PDF file.

\section{Acknowledgment}

Fabrina R. S. Bentlin would like to thank CAPES (Coordenação de Aperfeiçoamento de Pessoal de Nivel Superior) for the scholarship.

\section{References}

1. Rao, T. P.; Biju, V. M.; Crit. Rev. Anal. Chem. 2000, 30, 179.

2. Ornatsky, O. I.; Kinach, R.; Bandura D. R.; Lou, X.; Tanner, S.; Baranov, V.; Nitz, M.; Winnik, M. A.; J. Anal. At. Spectrom. 2008, 23, 463 .

3. Jakubowski, N.; Waentig, L.; Hayen, H.; Venkatachalam, A.; Von Bohlen, A.; Roos, P. H.; Manz, A.; J. Anal. At. Spectrom. 2008, 23, 1497.

4. Miaokang, S.; Yinyu, S.; J. AOAC Int. 1992, 75, 667.

5. Combs; D. K.; Satter, L. D.; J. Dairy Sci. 1992, 75, 2176.

6. Wang, Z.; Li, D.; Lu, P.; Wang, C.; J. Environ. Qual. 2001, 30, 37.

7. Coguel, R. L.; St. John, D. A.; Cem. Concr. Res. 1993, 23, 59.

8. Worrall, F.; Pearson, D.G.; Appl. Geochem. 2001, 16, 1465.

9. MacFadden, B.J.; Labs-Hochstein, J.; Hulbert, R.C.; Baskin, J.A.; Geology 2007, 35, 123.

10. Zhang, S.; Shan, X.; Environ. Pollut. 2001, 112, 395.

11. Palasz, A.; Czekaj, P.; Acta Biochim. Pol. 2000, 47, 4.

12. Lennart, W.; Lars, R.C.W.; Verhoof, V.W.; Timo, H.; Environ. Sci. Technol. 2004, 24. 6597.

13. Fricker, S. P.; Chem. Soc. Rev. 2006, 35, 524. 
14. Danko, B.; Dybczyński, R. S.; Samczyński Z.; J. Radioanal. Nucl. Chem. 2008, 27, 81.

15. Donati, G.L.; Gu, J.; Nóbrega, J.A.; Calloway, C.P.; Jones, B.T.; J. Anal. At. Spectrom. 2008, 23, 361.

16. Gásquez, J.A.; De Lima, E.; Roberto, A.; Martinez, O.L.D.; De La Guardia, M.; Talanta 2005, 67, 824.

17. Premadas, A.; Khorge, C.R.; At. Spectrosc. 2006, 27, 170.

18. Sileiman, J. S.; Huang, C.Z.; Pu, X.L.; Zhang, N.; Hu, B.; At. Spectrosc. 2006, 27, 200.

19. Kulkarni, P.; Chellam, S.; Fraser, M. P.; Atmos. Environ. 2006, 40, 508 .

20. Navarro, M. S.; Ulbrich, H. H. G. J.; Andrade, S.; Janasi, V. A.; J. Alloys Compd. 2002, 344, 40.

21. Lara, R.; Olsina, R. A.; Marchevsky, E.; Gásquez, J. A.; Martinez, L. D.; At. Spectrosc. 2000, 21, 172.

22. Longerich, H. P.; Fryer, B.J.; Strong, D. F.; Kantipuly, C.J.; Spectrochim. Acta, Part B 1987, 42, 75.

23. Dresssler, V.L.; Pozebon, D.; Matusch, A.; Becker, J.S.; Int. J. Mass Spectrom. 2007, 266, 25.

24. D’Ilio, S.; Violante, N.; Caime, S.; Gregório, D.; Petrucci, F.; Senofonte O.; Anal. Chim. Acta 2006, 432, 573.
25. Fragnière, C.; Haldimann, M.; Eastgate, A.; Krähenbühl, U.; J. Anal. At. Spectrom. 2005, 20, 626.

26. Paulenova, A.; Yu, M.; Alyapyshev, V.; Babain, A.; Herbst, R. S.; Law, J. D.; Sep. Sci. Technol. 2008, 42, 439.

27. Kolibarska, I.; Velichkov, S.; Daskalova, N.; Spectrochim. Acta, Part B 2008, 63, 603.

28. Sulcek, Z.; Rubeska, I.; Sixta, V.; Paukert, T.; At. Spectrosc. 1989, $10,4$.

29. Tognoni, E.; Hidalgo, M.; Canals, A.; Cristoforetti, G.; Legnaioli, S.; Salvetti, A.; Palleschi, V.; Spectrochim. Acta, Part B 2007, 62, 435 .

30. Trevisan, L. C.; Vieira, E. C.; Nogueira, A. R. A.; Nóbrega, J. A.; Spectrochim. Acta, Part B 2005, 60, 575.

31. Borkowska-Burnecka, J.; Leśniewicz, A.; Żyrnicki, W.; Spectrochim. Acta, Part B 2006, 61, 579.

32. Grotti, M.; Cristina Lagomarsino, C.; Mermet, J.M.; J. Anal. At. Spectrom. 2006, 21, 963.

33. Tarr, M. A.; Zhu, G.; Browner, R. F.; Appl. Spectrosc. 1991, 45, 1424.

Received: August 5, 2009

Web Release Date: December 15, 2009 


\title{
Direct Determination of Lanthanides in Environmental Samples using Ultrasonic Nebulization and ICP OES
}

\author{
Fabrina R. S. Bentlin and Dirce Pozebon*
}

Instituto de Química, Universidade Federal do Rio Grande do Sul, Av. Bento Gonçalves, 9500,

91501-970 Porto Alegre - RS, Brazil

Table S1. Spectral lines of the lanthanides elements and respective ICP OES limits of detection values (in $\left.\mu \mathrm{g} \mathrm{L}^{-1}\right)$ as a function of the nebulizer and plasma view

\begin{tabular}{|c|c|c|c|c|}
\hline \multirow{3}{*}{$\begin{array}{l}\text { Element/ } \\
\text { Spectral Line }\end{array}$} & \multicolumn{4}{|c|}{ Nebulizer and Plasma View } \\
\hline & \multicolumn{2}{|c|}{ Pneumatic } & \multicolumn{2}{|c|}{ Ultrasonic } \\
\hline & Axial & Radial & Axial & Radial \\
\hline La (II) 398.852 & 0.164 & 0.818 & 0.0096 & 0.0726 \\
\hline La (II) 408.672 & 0.442 & 1.00 & 0.0183 & 0.103 \\
\hline La (II) 379.478 & 0.304 & 0.886 & 0.0129 & 0.0921 \\
\hline La (II) 333.749 & 0.204 & 0.899 & 0.0267 & 0.358 \\
\hline La (II) 379.083 & 0.214 & 1.45 & 0.0105 & 0.0849 \\
\hline La (II) 403.169 & 0.482 & 1.34 & 0.0185 & 0.0753 \\
\hline La (II) 407.733 & 0.368 & 0.842 & 0.0153 & 0.150 \\
\hline La (II) 384.902 & 0.533 & 1.90 & 0.250 & 0.259 \\
\hline Ce (II) 413.764 & 2.12 & 4.98 & 0.244 & 0.691 \\
\hline Ce (II) 418.660 & 2.32 & 7.48 & 0.0996 & 0.229 \\
\hline Ce (II) 413.380 & 1.44 & 4.80 & 0.0693 & 0.272 \\
\hline Ce (II) 394.274 & 4.98 & 9.52 & 0.127 & 0.529 \\
\hline Ce (II) 456.236 & 2.41 & 4.11 & 0.0756 & 0.577 \\
\hline $\operatorname{Pr}$ (II) 390.844 & 0.834 & 3.40 & 0.0408 & 0.206 \\
\hline $\operatorname{Pr}$ (II) 414.311 & 1.11 & 2.77 & 0.0357 & 0.237 \\
\hline Pr (II) 422.293 & 2.08 & 3.31 & 0.0204 & 0.247 \\
\hline Nd (II) 406.109 & 1.25 & 2.70 & 0.0594 & 0.193 \\
\hline $\mathrm{Nd}$ (II) 401.225 & 1.62 & 7.76 & 0.0474 & 0.203 \\
\hline Nd (II) 430.358 & 2.46 & 4.91 & 0.0492 & 0.283 \\
\hline Nd (II) 424.738 & 6.41 & 7.22 & 0.0469 & 0.304 \\
\hline $\mathrm{Nd}$ (II) 384.824 & 7.16 & 18.0 & 0.123 & 0.709 \\
\hline Sm (II) 359.260 & 2.08 & 3.40 & 0.0387 & 0.221 \\
\hline Sm (II) 442.434 & 3.54 & 11.6 & 0.215 & 0.124 \\
\hline Sm (II) 360.949 & 0.804 & 2.02 & 0.0615 & 0.417 \\
\hline Sm (II) 388.529 & 1.08 & 3.48 & 0.0906 & 0.388 \\
\hline Sm (II) 428.079 & 1.63 & 6.97 & 0.0909 & 0.338 \\
\hline Eu (II) 381.967 & 0.0342 & 0.140 & 0.0027 & 0.019 \\
\hline $\mathrm{Eu}$ (II) 412.970 & 0.0642 & 0.187 & 0.0030 & 0.0210 \\
\hline
\end{tabular}

\begin{tabular}{|c|c|c|c|c|}
\hline \multirow{3}{*}{$\begin{array}{l}\text { Element/ } \\
\text { Spectral Line }\end{array}$} & \multicolumn{4}{|c|}{ Nebulizer and Plasma View } \\
\hline & \multicolumn{2}{|c|}{ Pneumatic } & \multicolumn{2}{|c|}{ Ultrasonic } \\
\hline & Axial & Radial & Axial & Radial \\
\hline Eu (II) 393.048 & 0.0666 & 0.273 & 0.0051 & 0.0483 \\
\hline Gd (II) 342.247 & 0.196 & 0.659 & 0.0117 & 0.106 \\
\hline Gd (II) 336.223 & 0.875 & 2.22 & 0.105 & 0.378 \\
\hline Gd (II) 335.047 & 0.504 & 2.68 & 0.0360 & 0.309 \\
\hline Gd (II) 376.839 & 0.701 & 2.15 & 0.0246 & 0.191 \\
\hline $\mathrm{Tb}$ (II) 350.917 & 0.349 & 1.94 & 0.0276 & 0.211 \\
\hline $\mathrm{Tb}$ (II) 384.873 & 0.643 & 3.26 & 0.0425 & 0.165 \\
\hline $\mathrm{Tb}$ (II) 367.635 & 1.35 & 4.61 & 0.0393 & 0.239 \\
\hline Dy (II) 353.170 & 0.165 & 0.579 & 0.0072 & 0.0450 \\
\hline Dy (II) 364.540 & 0.252 & 1.09 & 0.0159 & 0.145 \\
\hline Dy (II) 394.468 & 0.557 & 2.19 & 0.0478 & 0.131 \\
\hline Dy (II) 407.796 & 2.56 & 8.28 & 0.0495 & 0.226 \\
\hline Ho (II) 339.898 & 0.460 & 2.68 & 0.0198 & 0.154 \\
\hline Ho (II) 347.426 & 0.645 & 1.03 & 0.0767 & 0.162 \\
\hline Но (II) 345.600 & 0.167 & 0.511 & 0.0078 & 0.065 \\
\hline Er (II) 337.271 & 0.273 & 0.518 & 0.0117 & 0.0426 \\
\hline Er (II) 369.265 & 0.492 & 1.15 & 0.0156 & 0.0848 \\
\hline Er (II) 349.910 & 0.161 & 0.922 & 0.0129 & 0.137 \\
\hline Tm (II) 384.802 & 0.433 & 1.05 & 0.0090 & 0.0798 \\
\hline $\operatorname{Tm}$ (II) 346.220 & 0.486 & 1.72 & 0.0213 & 0.0984 \\
\hline $\operatorname{Tm}$ (II) 313.126 & 0.453 & 1.26 & 0.0123 & 0.0192 \\
\hline Tm (II) 336.261 & 0.570 & 1.98 & 0.0282 & 0.249 \\
\hline Tm (II) 324.154 & 2.49 & 4.26 & 0.0651 & 0.265 \\
\hline $\mathrm{Yb}$ (II) 369.419 & 0.0297 & 0.116 & 0.0012 & 0.0699 \\
\hline $\mathrm{Yb}$ (II) 328.937 & 0.0177 & 0.0600 & 0.0027 & 0.0898 \\
\hline $\mathrm{Yb}$ (II) 289.138 & 0.127 & 0.762 & 0.0177 & 0.152 \\
\hline Lu (II) 261.542 & 0.0171 & 0.124 & 0.0030 & 0.0135 \\
\hline Lu (II) 291.139 & 0.0933 & 0.858 & 0.0151 & 0.141 \\
\hline
\end{tabular}

*e-mail: dircepoz@iq.ufrgs.br 